\title{
Obesity as a Risk Factor Against COVID-19
}

\author{
Rosa Elvira Minchala Urgilés 1, 2, *, Anabel Estefanía Arce Prieto ${ }^{1}$, \\ Andrés Alexis Ramírez Coronel ${ }^{1,3}$, Lilia Romero Sacoto ${ }^{1}$, Fanny González León ${ }^{1}$, \\ María De Los Ángeles Estrella-González ${ }^{1}$, Pedro Carlos Martínez-Suárez ${ }^{3}$ \\ ${ }^{1}$ Faculty of Nursing, Catholic University of Cuenca, Azogues, Ecuador \\ ${ }^{2}$ José Carrasco Arteaga Specialty Hospital, Cuenca, Ecuador \\ ${ }^{3}$ Laboratory of Psychometry and Cognitive Neurosciences of the Center for Research, Innovation and Technology Transfer, Catholic \\ University of Cuenca, Cuenca, Ecuador
}

\section{Email address:}

rosa.minchala@ucacue.edu.ec(R. E. M. Urgilés)

${ }^{*}$ Corresponding author

\section{To cite this article:}

Rosa Elvira Minchala Urgilés, Anabel Estefanía Arce Prieto, Andrés Alexis Ramírez Coronel, Lilia Romero Sacoto, Fanny González León, María De Los Ángeles Estrella-González, Pedro Carlos Martínez-Suárez. Obesity as a Risk Factor Against COVID-19. Science Journal of Clinical Medicine. Vol. 10, No. 2, 2021, pp. 30-37. doi: 10.11648/j.sjcm.20211002.13

Received: April 22, 2021; Accepted: May 21, 2021; Published: May 31, 2021

\begin{abstract}
In late 2019, in Wuhan City, China, SARS-CoV2 was identified as the cause of an outbreak of acute respiratory illness called COVID-19 representing its most frequent lethal complication. Objective: To analyze, by means of a literature review, obesity as a risk factor for COVID-19. Methodology: A systematic review of the literature was carried out in scientific databases such as: Latin American and Caribbean Health Sciences Literature (LILACS); Virtual Health Library (VHL): Wiley Online Library and Medical Literature Analysis and Retrieval System Online (MEDLINE), Scielo, Scopus. The search terms included the study variables. Results: According to the analysis of 51 articles, it was determined that obese, male and elderly patients are the profile most prone to present respiratory system failures associated with COVID-19. Their pictures are aggravated by immunological and hormonal physiopathology typical of obesity; in addition, comorbidity in which there is diabetes, hypertension, cardiovascular diseases and obstructive pulmonary disease aggravates the picture of COVID-19 in obese patients. Conclusions: The presence of obesity is indeed a risk factor against COVID-19 infection, since it increases the possibility of suffering severe respiratory conditions.
\end{abstract}

Keywords: COVID-19, Obesity, Risk Factors, Comorbidity

\section{Introduction}

The World Health Organization defines obesity as an abnormal or excessive deposit of fat, so it adopts a simple way to measure obesity, which is the calculation of the Body Mass Index (BMI), which is obtained by weight in kilograms divided by size in square meter; therefore, if a person with a BMI equal to or greater than 30 is considered obese and if it is equal to or greater than 25 is considered overweight [1].

Coronavirus (COVID-19) caused by severe acute respiratory syndrome (SARS-CoV-2) has attracted increasing global attention [2], because its sudden outbreak and global spread represent one of the greatest public health challenges of modern times [3]. Thus, on 30 January 2020, the World Health Organization (WHO) declared the new coronavirus epidemic, now called coronavirus disease 2019 (COVID-19), a public health condition of international concern [4].

The epidemic has led to worldwide research efforts to identify the population most at risk of developing a critical disease and dying. Initial data indicated that older people are particularly vulnerable, as well as those with diabetes or cardiovascular (including hypertension), respiratory or kidney disease [5]. However, other studies have determined that symptomatology can even affect patients younger than 60 years of age and even involve asymptomatic symptoms [6]. These problems are often concentrated in certain racial groups (e.g., African Americans and Asians) which also appear to be more prone to the worst outcomes of COVID-19 [7]. An increasing number of reports have linked obesity to more serious diseases and death from COVID-19 [4, 5]. 
The new coronavirus disease (COVID-19) was first reported on 31 December 2019 and has spread worldwide. The mortality rate of patients with COVID-19 increases when the conditions are complicated with conditions such as diabetes, cardiovascular diseases, hypertension and other underlying diseases Taking into account the large number of elderly people with other diseases in the outbreak areas, the efforts to prevent and control the pandemic have been insufficient and the control of its spread in the world has been an emerging public health problem [8].

\subsection{Background}

Obesity is very prevalent in the United States and Europe, with an incidence of more than $40 \%$ [9, 10]. It can cause diabetes, cardiovascular diseases, vascular diseases and tumors, all associated with the susceptibility or higher mortality of COVID-19 [11, 12].

Studies indicate that obese patients with COVID-19 are more likely to receive mechanical ventilation and have a higher mortality rate [13]. These facts remind us that obesity may be closely related to the worsening of COVID-19. At the same time, at the same time they suggest that there are no differences in body mass index (BMI) between serious and non-serious groups $[14,15]$.

In the United Kingdom, $72.1 \%$ of 775 patients diagnosed with COVID-19 were found to be overweight or obese with a BMI $>30$, of whom $60.9 \%$ died [15]. In Italy, the prevalence of obesity was identified in $10.0 \%$ of a population of 1290 deceased patients, after an analysis of their respective clinical histories [16]. In France, obesity and severe obesity were present in $47.6 \%$ and $28.2 \%$ of patients requiring invasive mechanical ventilation (IVM) [13].

A study conducted in Cuenca-Ecuador, with 318 individuals of both sexes, presents the prevalence of obesity of $23.6 \%$ (27.5\% in women and $18.4 \%$ in men). Then the risk factor that showed the greatest association was type 2 diabetes mellitus, followed by high blood pressure and high daily calorie consumption [17].

\subsection{Obesity as a Risk Factor for Complications of COVID-19}

Obesity is considered a factor associated with morbidity and premature mortality in world statistics, while its health consequences are several [18]. In addition, studies have determined that obese people have a higher risk of complications in relation to more than twenty chronic diseases such as type 2 diabetes, hypertension, dyslipidemia, cardiovascular diseases, stroke, sleep apnea and some types of cancer $[13,18,19]$. Obesity is associated with a decrease in the volume of expiratory reserve, functional capacity and distensibility of the respiratory system. In addition, the increase in inflammatory cytokines associated with obesity may contribute to the increased morbidity associated with obesity in COVID-19 infections [20].

Psychosocial stress reactions increase energy intake and individuals with limited social interactions are at increased risk of developing obesity [3]. In addition, health fragility is known to generate a poor immune response, as well as a decrease in functional reserve [21], so human emotional health is also an important associated factor in the analysis of related conditions.

\subsection{Sociodemographic Factors of Obese Patients with COVID-19}

Obesity is a global disease with at least 2.8 million people dying each year from the consequences of overweight, according to World Health Organisation figures [22]. In addition, there is growing evidence to suggest that the results of coronavirus disease 2019 (COVID-19) are worse in those with obesity and that a significant proportion of those in need of intensive care are overweight [23].

The prevalence of adult obesity and severe obesity in 2017 to 2018 has increased with respect to measurements from 2009 to 2010 and reached $42 \%$ and $9 \%$, respectively [9]. These observations suggest that the proportion of patients with severe obesity and COVID-19 infections will increase, and the disease will likely have a more severe course in these patients [20].

The relationship between sociodemographic characteristics and mortality of patients hospitalized with COVID-19 presents particularities, considering some factors such as racial: it was known that black patients, Mestizos and indigenous people were less frequently admitted to the ICU and were more frequently intubated than white and Asian patients. These populations are more likely to suffer from chronic diseases, which increases their risk of mortality associated with COVID-19 [24].

China's first reports pointed to a gender imbalance in detected cases and lethality rate, however, there is no comprehensive analysis of the underlying causes [25]. While the disease has spread across several continents, the research initiative "Global Health 5050" presented a breakdown of the disease by sex in countries around the world, showing that there would be a similar number of cases in women and men, but higher mortality in men [26].

With regard to age, it is known that the susceptibility to infection in people under 20 years of age is about half that in adults over 20 years of age. Clinical symptoms are evident in $21 \%$ of infections in people aged $10-19$ years, and increase to $69 \%$ in infections in people over 70 years of age [27]. Data from China show that the case fatality rate of COVID-19 increases with age, ranging from $0.4 \%$ in patients up to age 40 ; by $1.3 \%$ between the age of 60 ; by $8 \%$ at age 70 and increasing by $14.8 \%$ from age 80 . In comparison, the overall mortality rate is $2.8 \%$ worldwide and $2.7 \%$ in the U.S. [28]. This information has implications for the projected global burden of COVID-19, as a result of demographic differences between different environments.

\subsection{Pathophysiology and Clinical Manifestations of Obesity and Involvement to COVID-19}

In the perspective of identifying and clarifying the main pathophysiological mechanisms that lead to increased 
susceptibility and severity of COVID-19 and obesity per se, the following information may be cited.

It has been established that due to secretion of macrophages from adipose tissue of the M1 phenotype, people with obesity have higher circulating levels of proinflammatory cytokines such as IL-1 $\beta$, IL-6, IL-12, TNF$\alpha$ and MCP-1 [29]. In addition, the imbalance in the production of leptin and adiponectin also creates an unfavourable hormonal environment that generates and maintains a chronic proinflammatory state [30].

At the immunological level, obesity also affects the response mediated by CD8 T lymphocytes, which are of vital importance for the response to viruses, with the possibility of aggravating the clinical picture. Attached to the immune response, obesity is associated with impaired ventilation of the base of the lungs, decreasing the volume of expiratory reserve, functional capacity and compliance of the respiratory system, which hinders the ventilation of these patients by reducing oxygen saturation. Obesity along with its associated pathologies such as dyslipidemia, type 2 diabetes mellitus, hypertension and cardiovascular disease could play an important role in the immune system of the host infected with SARS-CoV-2 [13, 28, 29].

Among the clinical manifestations of obesity are several gastrointestinal complications such as upper abdominal pain, diarrhea, gastroesophageal reflux disease, vesicular lithiasis, non-alcoholic hepatic steatosis and other less studied chronic gastrointestinal symptoms, such as irritable bowel syndrome and lower abdominal pain. Likewise, the body mass index and abdominal perimeter are risk factors for severity and mortality in patients with acute pancreatitis [31].

It is important to note that, in patients with obesity, when an antigen is present, the activation of macrophages is reduced and the production of proinflammatory cytokines is reduced after the stimulation of macrophages, as well as a poor response of $\mathrm{B}$ and $\mathrm{T}$ cells, due to chronic low-grade inflammation linked to obesity [30]. Both situations lead to increased susceptibility to viral infection and prolonged viral spread [32].

SARS-CoV-2 contains about 30,000 bases of RNA, the same that uses the protein $S$ (spike) with a glycosylated dense structure to enter host cells and binds with great affinity to the angiotensin converting enzyme receptor (ACE2), This enzyme is found in alveolar cells type II. In the cells of the upper and lower respiratory tract, RNA enters and is converted to viral proteins. This results from two processes: Direct cytopathic effect that deals with viral infection, which prevails in the early stages of the pathology; and the second process is the inflammatory response not controlled by the infected individual, which influences the last stages. The superimposition of these two pathophysiological processes results phenotypically in a 3stage evolution of the disease: early phase, pulmonary phase and hyperinflammatory phase [33].

The reduction in the stimulation of macrophages at the time of antigen presentation may even explain a possible low vaccination success in viral infections in general [30] and especially in the case of the virus causing COVID-19. The visible reduction in the effects of the disease will not be a reality until effective vaccines are given to a large part of the world's population, in such a way as to prevent the hospitalization and chronic status of COVID-19 [34].

\subsection{Comorbidity of Obese Patients Affected by COVID-19}

The first BMI investigations in critical patients hospitalized for COVID-19 infection (although with small samples) determined that approximately $85 \%$ of patients with obesity required mechanical ventilation [13]. Preliminary data from New York City showed that obesity (BMI $>40 \mathrm{~kg} /$ $\mathrm{m}^{2}$ ) is the second strongest independent predictor of hospitalization, after old age [7].

It has been determined that the cases of severe affection to the human organism by COVID-19 entail bilateral interstitial pneumonias that require assistance in intensive care (ICU) and can evolve to a respiratory distress syndrome, which has a high mortality [35]. The most common comorbidities are hypertension, cardiovascular disease, type 2 diabetes, and obstructive pulmonary disease $[35,36]$. Some research has determined that factors such as elevated serum triglycerides, total cholesterol, low-density lipoprotein cholesterol, blood pressure, ferritin, CRP, and low relative lymphocyte count are significant risk factors in obese COVID patients -19. Many studies have evaluated risk factors (age, sex, comorbidities) that may be related to complications and deaths. Studies to date have shown a worldwide predominance of older men, as well as those with cardiovascular disease, in adverse outcomes from COVID-19 [37].

With its increasing prevalence, obesity is an important risk factor for many noncommunicable diseases [38]. A recent meta-analysis has shown that obesity-associated complications are important risk factors for severe acute respiratory syndrome coronavirus 2 (SARS-CoV2) infection. In a total of 1,558 COVID-19 patients in 6 studies, the likelihood ratio (LR) was determined for each comorbidity. The following results were obtained: $\mathrm{PC}$ in hypertension: 2.29, $\mathrm{P}<0.001$ ); $\mathrm{CP}$ in diabetes: $2.47, \mathrm{P}<0.00$; $\mathrm{PC}$ in chronic obstructive pulmonary disease (COPD): 5.97, $\mathrm{P}<0.001$; $\mathrm{PC}$ in cardiovascular disease: 2.93, $\mathrm{P}<0.001$ and $\mathrm{PC}$ in cerebrovascular disease: $3.89, \mathrm{P}=0.002$ [39]. Consequently, hypertension, diabetes, COPD,

In obese patients, excess adipocytes can potentiate immune and inflammatory changes [40]. Increased adipose tissue mass is a well-known contributing factor in proinflammatory cascades [41]. SARS-CoV2, which causes the current global COVID-19 pandemic of global proportions, has a high affinity for angiotensin-converting enzyme 2 (human ACE2) $[42,43]$. ACE2 receptors show increased gene expression in adipose tissue [44] Therefore, excess body fat increases ACE2 receptors and may increase the risk of SARS-CoV2 infection and developing a severe form of COVID-19 [25].

\section{Methodology}

To analyze, through a bibliographic review, obesity as a risk factor for complications of COVID-19, a theoretical and 
interpretive approach was used. In this framework, the methodological strategy with which the conceptualizations and findings that delimit the object of study were addressed was the qualitative systematic review of bibliographic sources.

The search and selection of documentary sources was carried out in three phases, based on the application of tracking criteria. These included the following terms: COVID-19; obesity; obesity; socio-demographic factors; socio-demographic factors; pathophysiology of obesity; pathophysiology of obesity; obese patient comorbidities; comorbidities of obesity.

Phase 1: Use of Boolean operators.

To track information in databases, two logical operators (Boolean) were used: "AND" to include two or more terms in the same search and "OR" to obtain explorations that include at least one of the terms required.

Table 1. Equations and results of the search process.

\begin{tabular}{|c|c|c|c|c|}
\hline \multirow{2}{*}{ Applied equation } & \multicolumn{4}{|l|}{ Results } \\
\hline & LILACS & VHL & Wiley Online Library & MEDLINE \\
\hline "COVID-19" AND "obesity" & 37 & 490 & 14 & Four. Five \\
\hline "COVID-19" AND "obesity" & 43 & 1351 & 1807 & 1589 \\
\hline "COVID-19" OR "obesity" AND "socio-demographic factors" & 206 & 2631 & 22575 & 281 \\
\hline "COVID-19" OR "obesity" AND "socio-demographic factors" & 53 & 180 & 21818 & 0 \\
\hline "COVID-19" AND "obesity" OR "pathophysiology of obesity" OR "comorbidities of obesity" & 42 & 1485 & 2607 & 23963 \\
\hline “COVID-19” AND “obesity” OR “obesity pathophysiology” OR “obese patient comorbidities” & 0 & 3 & 456 & 2544 \\
\hline
\end{tabular}

\section{Phase 2: Inclusion and exclusion criteria.}

After the initial information tracing with the stated equations, filters were applied to the results obtained; This procedure gave way to the specificity of the publications according to the following inclusion criteria: Scientific articles, published in the last five years, in English and Spanish. Duplicate studies, from repositories, difficult to translate and interpret, that do not present the abstract or the text, or were subscription-based, were excluded.

Phase 3: Exploration techniques.

The variables that make up the object of study were determined to apply them as bibliographic search terms. COVID-19. Obesity, risk factors, comorbidity. The databases that collect publications related to research in the Health area were investigated. Latin American and Caribbean Health Sciences Literature (LILACS), Virtual Health Library (VHL), Wiley Online Library, Medical Literature Analysis and Retrieval System Online (MEDLINE).
A first information search was carried out on the identified variables, in such a way that the exclusion criteria that led to a more specific search for information could then be defined. A classification matrix of the selected documents was elaborated, which contained descriptive categories of the analyzed information: search equation; publication date; authors; publication title; summary or abstract; guiding question; Methodological approach; results; conclusions; database in which the publication is hosted.

\section{Results}

After applying the inclusion criteria, 91 publications were found, of which 32 required a paid subscription and, therefore, were excluded from the analysis. 59 bibliographies of which 8 did not meet the objectives; Therefore, a total of 51 bibliographies were cited, 2 of these were from web pages such as WHO and PAHO.

Table 2. Metadata matrix (20 most recent posts).

\begin{tabular}{|c|c|c|c|c|c|c|}
\hline No & Magazine & Publication title & Authors & $\begin{array}{l}\text { Year of } \\
\text { publication }\end{array}$ & Idiom & Target covered \\
\hline 1 & Dovepress Journal. & $\begin{array}{l}\text { Impact of Obesity and Its } \\
\text { Associated Comorbid Conditions } \\
\text { on COVID-19 Presentation }\end{array}$ & $\begin{array}{l}\text { Mehanna, Osama } \\
\text { Askary, Ahmad El Ali, } \\
\text { Ebtesam } \\
\text { Esawy, Basem El }\end{array}$ & 2021 & English & $\begin{array}{l}\text { "To determine the } \\
\text { comorbidities of obese patients } \\
\text { affected by COVID-19". }\end{array}$ \\
\hline 2 & The Lancet & $\begin{array}{l}\text { Challenges in ensuring global } \\
\text { access to COVID-19 vaccines: } \\
\text { production, affordability, } \\
\text { allocation, and deployment. }\end{array}$ & $\begin{array}{l}\text { Olivier J Wouters, Kenneth } \\
\text { C Shadlen, Maximilian } \\
\text { Salcher-Konrad, Andrew J } \\
\text { Pollard, et al. }\end{array}$ & 2021 & English & $\begin{array}{l}\text { "Identify the sociodemographic } \\
\text { factors of obese patients } \\
\text { affected with COVID-19". }\end{array}$ \\
\hline 3 & $\begin{array}{l}\text { Aging Research } \\
\text { Reviews journal }\end{array}$ & $\begin{array}{l}\text { Aging in COVID-19: } \\
\text { Vulnerability, immunity and } \\
\text { intervention } \\
\text { Yiyin }\end{array}$ & $\begin{array}{l}\text { Chen, Yiyin } \\
\text { Klein, Sabra L. } \\
\text { Garibaldi, } \\
\text { Et al. } \\
\text { Peres, IT }\end{array}$ & 2021 & English & $\begin{array}{l}\text { "Identify the sociodemographic } \\
\text { factors of obese patients } \\
\text { affected with COVID-19". }\end{array}$ \\
\hline 4 & Public Health & $\begin{array}{l}\text { Sociodemographic factors } \\
\text { associated with COVID-19 in- } \\
\text { hospital mortality in Brazil }\end{array}$ & $\begin{array}{l}\text { Wands, LSL } \\
\text { Mayrinck Gelli, JG } \\
\text { Marchesi, JF } \\
\text { Dantas, LF } \\
\text { et al. }\end{array}$ & 2021 & English & $\begin{array}{l}\text { "Identify the sociodemographic } \\
\text { factors of obese patients } \\
\text { affected with COVID-19". }\end{array}$ \\
\hline 5 & The Lancet & $\begin{array}{l}\text { Obesity could shift severe } \\
\text { COVID-19 disease to younger } \\
\text { ages }\end{array}$ & $\begin{array}{l}\text { Kass, David A. } \\
\text { Duggal, Priya } \\
\text { Cingolani, Oscar }\end{array}$ & 2020 & English & $\begin{array}{l}\text { "Identify the sociodemographic } \\
\text { factors of obese patients } \\
\text { affected with COVID-19" }\end{array}$ \\
\hline
\end{tabular}




\begin{tabular}{|c|c|c|c|c|c|c|}
\hline No & Magazine & Publication title & Authors & $\begin{array}{l}\text { Year of } \\
\text { publication }\end{array}$ & Idiom & Target covered \\
\hline 6 & $\begin{array}{l}\text { Obesity Medicine } \\
\text { journal }\end{array}$ & $\begin{array}{l}\text { The relationship between obesity } \\
\text { and other medical comorbidities }\end{array}$ & $\begin{array}{l}\text { Afolabi, Hafeez Abiola } \\
\text { Zakariya, Zaidi bin } \\
\text { Ahmed Shokri, Amran Bin } \\
\text { Mohammad Hasim, et al. }\end{array}$ & 2020 & English & $\begin{array}{l}\text { "To determine the } \\
\text { comorbidities of obese patients } \\
\text { affected by COVID-19". }\end{array}$ \\
\hline 7 & $\begin{array}{l}\text { Obesity Medicine } \\
\text { journal }\end{array}$ & $\begin{array}{l}\text { Association of high level gene } \\
\text { expression of ACE2 in adipose tissue } \\
\text { with mortality of COVID-19 } \\
\text { infection in obese patients }\end{array}$ & Al-Benna, Sammy & 2020 & English & $\begin{array}{l}\text { "To investigate the } \\
\text { pathophysiology and clinical } \\
\text { manifestations of obesity and } \\
\text { its involvement in COVID-19". }\end{array}$ \\
\hline 8 & $\begin{array}{l}\text { Obesity Medicine } \\
\text { journal }\end{array}$ & $\begin{array}{l}\text { Potential pathophysiological } \\
\text { mechanisms leading to increased } \\
\text { COVID-19 susceptibility and } \\
\text { severity in obesity }\end{array}$ & $\begin{array}{l}\text { Belančić, Andrej } \\
\text { Kresović, Andrea } \\
\text { Rački, Valentino }\end{array}$ & 2020 & English & $\begin{array}{l}\text { "To investigate the } \\
\text { pathophysiology and clinical } \\
\text { manifestations of obesity and } \\
\text { the implication to COVID-19". }\end{array}$ \\
\hline 9 & $\begin{array}{l}\text { The Journals of } \\
\text { Gerontology: Series } \\
\text { A }\end{array}$ & $\begin{array}{l}\text { Unequal Impact of Structural } \\
\text { Health Determinants and } \\
\text { Comorbidity on COVID-19 } \\
\text { Severity and Lethality in Older } \\
\text { Mexican Adults: Considerations } \\
\text { Beyond Chronological Aging }\end{array}$ & $\begin{array}{l}\text { Bello-Chavolla, Omar } \\
\text { Yaxmehen } \\
\text { González-Díaz, Armando } \\
\text { Antonio-Villa, et al. }\end{array}$ & 2020 & English & $\begin{array}{l}\text { "Determine the comorbidities } \\
\text { of obese patients affected by } \\
\text { COVID-19". }\end{array}$ \\
\hline 10 & $\begin{array}{l}\text { The Journal of } \\
\text { Clinical } \\
\text { Endocrinology \& } \\
\text { Metabolism }\end{array}$ & $\begin{array}{l}\text { Predicting mortality due to SARS- } \\
\text { CoV-2: A mechanistic score } \\
\text { relating obesity and diabetes to } \\
\text { COVID- } 19 \text { outcomes in Mexico }\end{array}$ & $\begin{array}{l}\text { Bello-Chavolla, Omar; } \\
\text { Bahena-López, Jessica; } \\
\text { Antonio-Villa, Neftali; } \\
\text { Vargas-Vázquez, et al. }\end{array}$ & 2020 & English & $\begin{array}{l}\text { "Determine the comorbidities } \\
\text { of obese patients affected by } \\
\text { COVID-19". }\end{array}$ \\
\hline eleven & Journal of Pathology & $\begin{array}{l}\text { Angiotensin-converting enzyme } 2 \\
\text { (ACE2), SARS-CoV-2 and the } \\
\text { pathophysiology of coronavirus } \\
\text { disease } 2019 \text { (COVID-19) }\end{array}$ & $\begin{array}{l}\text { Bourgonje, Arno R. } \\
\text { Abdulle, Amaal E. } \\
\text { Timens, et al et al. }\end{array}$ & 2020 & English & $\begin{array}{l}\text { "To investigate the } \\
\text { pathophysiology and clinical } \\
\text { manifestations of obesity and } \\
\text { the implication to COVID-19". }\end{array}$ \\
\hline 12 & Diabetes Care & $\begin{array}{l}\text { Obesity and COVID-19 Severity } \\
\text { in a Designated Hospital in } \\
\text { Shenzhen, China }\end{array}$ & $\begin{array}{l}\text { Cai, Qingxian } \\
\text { Chen, Fengjuan } \\
\text { Wang, } \\
\text { et al. }\end{array}$ & 2020 & English & $\begin{array}{l}\text { "To determine the } \\
\text { comorbidities of obese patients } \\
\text { affected by COVID-19". }\end{array}$ \\
\hline 13 & $\begin{array}{l}\text { Nature Reviews } \\
\text { Endocrinology }\end{array}$ & $\begin{array}{l}\text { Will the COVID- } 19 \text { pandemic } \\
\text { worsen the obesity epidemic? }\end{array}$ & $\begin{array}{l}\text { Clemmensen, Christoffer } \\
\text { Petersen, Michael Bang } \\
\text { Sørensen, Thorkild IA }\end{array}$ & 2020 & English & $\begin{array}{l}\text { "Identify the sociodemographic } \\
\text { factors of obese patients } \\
\text { affected with COVID-19". }\end{array}$ \\
\hline 14 & Obesity & $\begin{array}{l}\text { Obesity and its Implications for } \\
\text { COVID-19 Mortality }\end{array}$ & $\begin{array}{l}\text { Dietz, William } \\
\text { Santos-Burgoa, Carlos }\end{array}$ & 2020 & English & $\begin{array}{l}\text { "To determine the } \\
\text { comorbidities of obese patients } \\
\text { affected by COVID-19". }\end{array}$ \\
\hline fifteen & Diabetes Care & $\begin{array}{l}\text { Obesity Is a Risk Factor for } \\
\text { Greater COVID-19 Severity }\end{array}$ & $\begin{array}{l}\text { Gao, Feng Zheng, Kenneth I. } \\
\text { Wang, Xiao Bo Sun, Qing } \\
\text { Feng Pan et al. }\end{array}$ & 2020 & English & $\begin{array}{l}\text { "To determine the } \\
\text { comorbidities of obese patients } \\
\text { affected by COVID-19". }\end{array}$ \\
\hline 16 & $\begin{array}{l}\text { Obesity Research } \\
\text { and Clinical Practice }\end{array}$ & $\begin{array}{l}\text { Obesity and mortality of COVID- } \\
\text { 19. Meta-analysis }\end{array}$ & $\begin{array}{l}\text { Hussain, Abdulzahra } \\
\text { Mahawar, Kamal Xia, } \\
\text { Zefeng Yang, et al. }\end{array}$ & 2020 & English & $\begin{array}{l}\text { "To determine the } \\
\text { comorbidities of obese patients } \\
\text { affected by COVID-19". }\end{array}$ \\
\hline 17 & $\begin{array}{l}\text { Biology of Sex } \\
\text { Differences }\end{array}$ & $\begin{array}{l}\text { Impact of sex and gender on } \\
\text { COVID-19 outcomes in Europe }\end{array}$ & $\begin{array}{l}\text { Klein, Sabra L. } \\
\text { Morgan, Rosemary }\end{array}$ & 2020 & English & $\begin{array}{l}\text { "Identify the sociodemographic } \\
\text { factors of obese patients } \\
\text { affected with COVID-19". }\end{array}$ \\
\hline 18 & $\begin{array}{l}\text { Diabetes and } \\
\text { Metabolism }\end{array}$ & $\begin{array}{l}\text { Body mass index and outcome in } \\
\text { patients with COVID-19: A dose- } \\
\text { response meta-analysis }\end{array}$ & $\begin{array}{l}\text { Pranata, R. } \\
\text { Lim, MA } \\
\text { Yonas, E. } \\
\text { Vania, et al }\end{array}$ & 2020 & English & $\begin{array}{l}\text { "Determine the comorbidities } \\
\text { of obese patients affected by } \\
\text { COVID-19". }\end{array}$ \\
\hline 19 & Obesity & $\begin{array}{l}\text { High Prevalence of Obesity in } \\
\text { Severe Acute Respiratory } \\
\text { Syndrome Coronavirus-2 (SARS- } \\
\text { CoV-2) Requiring Invasive } \\
\text { Mechanical Ventilation. }\end{array}$ & Simonnet, Arthur et al. & 2020 & English & $\begin{array}{l}\text { "Determine the comorbidities } \\
\text { of obese patients affected by } \\
\text { COVID-19" }\end{array}$ \\
\hline 20 & The Lancet & $\begin{array}{l}\text { Clinical course and risk factors for } \\
\text { mortality of adult inpatients with } \\
\text { COVID-19 in Wuhan, China: a } \\
\text { retrospective study }\end{array}$ & $\begin{array}{l}\text { Zhou, Fei Yu, Ting Du, } \\
\text { Ronghui Fan, et al. }\end{array}$ & 2020 & English & $\begin{array}{l}\text { "Clinical course and risk factors } \\
\text { for mortality of adult inpatients } \\
\text { with COVID-19 in Wuhan". }\end{array}$ \\
\hline
\end{tabular}

\section{Discussion}

Obesity has become a global public health problem, with a significant and profound impact on morbidity, mortality, and the cost of healthcare [45]. It has been established that obesity is, indeed, a risk factor for COVID-19, [22] because, on the one hand, it aggravates the chronicity of respiratory diseases by reducing lung function [3, 8], and immunological and inflammatory alterations $[20,21]$. Furthermore, the tendency of obese patients to develop a severe form of COVID-19 due to the accumulation of body fat is denoted $[22,46]$.

The implications of this disease in obese people include possible difficulties in handling diagnostic tests, as well as in treating COVID-19. It should also be noted that consequences associated with confinement with repercussions on the control and treatment of obesity have been established, so that the affection of this population would confirm their vulnerability to the pandemic [47].

The important role of some socioeconomic aspects has 
been demonstrated, although age is a significant predictor, comorbidities and structural health factors also determine the risk of fatality in elderly patients [44]. The COVID-19 pandemic has shown a markedly low proportion of cases among minors, attributed to these populations having a lower susceptibility to infection, a lower propensity to show clinical symptoms, or both. A study evaluated epidemic data by age in 26 countries, finding that clinical symptoms occur in $25 \%$ of infections in people aged 10 to 19 years; this figure increases to $76 \%$ in those older than 70 years [27].

It was highlighted that the symptoms of patients infected with COVID-19 tend to vary in a wide range; however, elderly men with cardiovascular disease and obesity show greater adverse outcomes from COVID-19 [18, 19]. According to the age factor, it was determined that the cases of contagion and the severity of the symptoms tend to rise in direct relation to the number of years.

The nervous system also appears to be susceptible to SARS-CoV2 denoting an intensified proinflammatory immune response, which can cause severe disturbances in central respiratory function, as well as cerebrovascular disease, seizures, and other symptoms such as loss of taste and smell [48]. The multi-organ involvement that COVD-19 causes includes the nervous system, ventilatory failures are evidenced in which there are no ventilation / perfusion imbalances on their own, but loss of hypoxic vasoconstriction reflexes has also been detected [49]. At the immunological level, obese people are affected in their ability to respond to viruses, as well as a deformed ventilation at the base of the lungs that leads to a serious affectation of the respiratory system [50].

Among the most common conditions caused by contagion of COVID-19 were bilateral interstitial pneumonias that entail assistance in intensive care (ICU). In addition, hypertension, cardiovascular disease, type 2 diabetes, and obstructive pulmonary disease [35, 36]. Among the main comorbidities and risk factors associated with mortality in people infected by COVID-19 are: diabetes mellitus (Risk ratio $=1.63$ ); systemic arterial hypertension $($ Hazard ratio $=1.48)$; obesity (Risk ratio $=$ 1.37 ) and chronic kidney damage (Risk ratio $=2.06$ ); it was established that the presence of comorbidities associated with the infection by SARS-CoV-2 actually increases the risk of mortality in people [51].

\section{Conclusions}

The study highlights that men over 65 years of age constitute the predominant profile among patients with the highest level of disease and morbidity. In addition, black, mestizo and indigenous populations have been identified as those most likely to suffer from chronic diseases, increasing their risk of mortality from COVID-19.

Metabolism disorders caused by obesity are related to cases of worsening symptoms of COVID-19. The unfavorable hormonal environment present in obese patients with COVID 19 , as well as the immune level of these people make them more prone to experiencing respiratory system malfunctions.

In comorbidity, the significance of obesity-related conditions was evidenced for patients with COVID-19, especially in cases of diabetes, hypertension, cardiovascular diseases and obstructive pulmonary disease; among the most common conditions caused by contagion of COVID-19 were bilateral interstitial pneumonias that entail assistance in intensive care.

There is evidence of the need to deepen the link between obesity and COVID-19 in order, in this way, to design prevention plans that can reduce the risks that are currently experienced in vulnerable populations.

\section{Conflicts of Interest}

The authors do not report conflicts of interest

\section{Acknowledgements}

To the Catholic University of Cuenca, Azogues Headquarters, to the Laboratory of Psychometry and Cognitive Neurosciences of the Center for Research, Innovation and Technology Transfer (CIITT) of the Catholic University of Cuenca.

\section{References}

[1] WHO. WHO | Obesity. WHO [Internet]. 2016 [cited 2021 Mar 25]; Available from: http://www.who.int/topics/obesity/es/

[2] OPS. Coronavirus (COVID-19) events as they happen [Internet]. WORLD HEALTH ORGANITATION. 2020 [cited 2021 Mar 25]. Available from: https://www.who.int/emergencies/diseases/novel-coronavirus2019/events-as-they-happen

[3] Clemmensen C, Petersen M, Sørensen A. Will the COVID-19 pandemic worsen the obesity epidemic? comment [Internet]. 2020; 16. Available from: https://www.

[4] Cai Q, Chen F, Wang T, Luo F, Liu X, Wu Q, et al. Obesity and COVID-19 Severity in a Designated Hospital in Shenzhen, China. Diabetes Care. 2020; 43 (7): 1392-8.

[5] Sattar N, McInnes IB, McMurray JJV. Obesity Is a Risk Factor for Severe COVID-19 Infection: Multiple Potential Mechanisms. Circulation. 2020; 44 (0): 4-6.

[6] Lighter J, Phillips M, Hochman S, Sterling S, Johnson D, Francois F, et al. Obesity in patients younger than 60 years is a risk factor for COVID-19 hospital admission [Internet]. Vol. 71, Clinical Infectious Diseases. Oxford University Press; 2020 [cited 2021 Mar 25]. p. 896-7. Available from: https://academic.oup.com/cid/article/71/15/896/5818333

[7] Petrilli C, Jones S, Yang J, Rajagopalan H, O'Donnell L, Chernyak $\mathrm{Y}$, et al. Factors associated with hospitalization and critical illness among 4,103 patients with Covid-19 disease in New York City. medRxiv. 2020; (646): 1-25.

[8] Gao F, Zheng KI, Wang XB, Sun QF, Pan KH, Wang TY, et al. Obesity Is a Risk Factor for Greater COVID-19 Severity. Diabetes Care. 2020; 43 (7): E72-4. 
[9] Hales CM, Carroll MD, Fryar CD, Ogden CL. Prevalence of Obesity and Severe Obesity Among Adults: United States, 2017-2018 Key findings Data from the National Health and Nutrition Examination Survey [Internet]. 2017 [cited 2021 Mar 25]. Available from: https://www.cdc.gov/nchs/products/index.htm.

[10] Marques A, Peralta M, Naia A, Loureiro N, De Matos MG. Prevalence of adultoverweight and obesity in 20 European countries, 2014. Eur J Public Health. 2018; 28 (2): 295-300.

[11] González-Muniesa P, Mártinez-González MA, Hu FB, Després JP, Matsuzawa Y, Loos RJF, et al. Obesity. Nat Rev Dis Prim. 2017; 3.

[12] Li B, Yang J, Zhao F, Zhi L, Wang X, Liu L, et al. Prevalence and impact of cardiovascular metabolic diseases on COVID19 in China. Clin Res Cardiol. 2020; 109 (5): 531-8.

[13] Simonnet A, Chetboun M, Poissy J, Raverdy V, Noulette J, Duhamel A, et al. High Prevalence of Obesity in Severe Acute Respiratory Syndrome Coronavirus-2 (SARS-CoV-2) Requiring Invasive Mechanical Ventilation. Obesity. 2020; 28 (7): 1195-9.

[14] Xiang T, Liu J XF. Analysis of clinical characteristics of 49 patients with coronavirus disease 2019 in Jiangxi [Internet]. Epistemonics. 2020 [cited 2021 Mar 25]. Available from: https://www.epistemonikos.org/documents/dbcd5d8a417acff8 $34 \mathrm{a} 4 \mathrm{a} 01 \mathrm{e} 025657387 \mathrm{fc} 1159 \mathrm{f}$

[15] EL-Arabey AA, Abdalla M. Metformin and COVID-19: A novel deal of an old drug. J Med Virol. 2020; 92 (11): 2293-4.

[16] Health E for public, Istituto Superiore di Sanità. Characteristics of SARS-CoV-2 patients dying in Italy Report. ISTITVTO SVPERIORE DI SANITA [Internet]. 2020; 4-8. Available from: https://www.epicentro.iss.it/en/coronavirus/sars-cov-2analysis-of-deaths $\% 0 \mathrm{~A}$ https://www.epicentro.iss.it/en/coronavirus/bollettino/Report COVID-2019_7_september_2020.pdf

[17] Campoverde ME, Añez R, Salazar J, Rojas J, Bermúdez V. Risk factors for obesity in adults from the city of Cuenca, Ecuador. Rev Latinoam Hipertens. 2016; 9 (3): 1-10.

[18] Di Angelantonio E, Bhupathiraju SN, Wormser D, Gao P, Kaptoge S, de Gonzalez AB, et al. Body-mass index and allcause mortality: individual-participant-datameta-analysis of 239 prospective studies in four continents. Lancet. 2016; 388 (10046): 776-86.

[19] Secretan BL, Ph D, Scoccianti C, Ph D, Loomis D, Ph D. Spe ci al R ep or t Body Fatness and Cancer - Viewpoint of the IARC Working Group. Med Spec. 2016; (Copyright): 794-8.

[20] Dietz W, Santos-Burgoa C. Obesity and its Implications for COVID-19 Mortality. Obesity. 2020; 28 (6): 1005.

[21] Pinazo-hernandis S. DAD E SPA AT Y GER ON TO Psychosocial impact of COVID-19 on older people: problems and challenges Psychosocial impact of COVID-19 on older people: Problems and challenges. Rev Esp Geriatr Gerontol [Internet]. 2020; 55 (5): 249-52. Available from: https://doi.org/10.1016/j.regg.2020.05.006

[22] Hussain A, Mahawar K, Xia Z, Yang W, EL-Hasani S. Obesity and mortality of COVID-19. Meta-analysis. Obes Res Clin Pract [Internet]. 2020; 14 (4): 295-300. Available from: https://doi.org/10.1016/j.orcp.2020.07.002
[23] Muscogiuri G, Pugliese G, Barrea L, Savastano S, Colao A. Commentary: Obesity: The \& quot; Achilles heel \& quot; for COVID-19? Metabolism [Internet]. 2020; 108 (January): 154251. Available from: http://www.ncbi.nlm.nih.gov/pubmed/32353356\%0A http://www.pubmedcentral.nih.gov/articlerender.fcgi?artid=P MC7184987

[24] Peres IT, Bastos LSL, Gelli JGM, Marchesi JF, Dantas LF, Antunes BBP. Since January 2020 Elsevier has created a COVID-19 resource center with free information in English and Mandarin on the novel coronavirus COVID-19. The COVID-19 resource center is hosted on Elsevier Connect, the company 's public news and information. Public Health. 2020; (January).

[25] Frühbeck G, Busetto L, Dicker D, Yumuk V, Goossens GH, Hebebrand J, et al. The ABCD of obesity: An EASO position statement on a diagnostic term with clinical and scientific implications. Obes Facts. 2019; 12 (2): 131-6.

[26] Global Health. The Sex, Gender and COVID-19 Project Global Health 50/50 [Internet]. March. 2021 [cited 2021 Mar 25]. Available from: https://globalhealth5050.org/the-sexgender-and-covid-19-project/

[27] Davies NG, Klepac P, Liu Y, Prem K, Jit M, Eggo RM, et al. Age-dependent effects in the transmission and control of COVID-19 epidemics. medRxiv. 2020.

[28] Chen Y, Klein SL, Garibaldi BT, Li H, Wu C, Osevala NM, et al. Aging in COVID-19: Vulnerability, immunity and intervention. Aging Res Rev. 2021; 65 (January).

[29] Wensveen FM, Valentić S, Šestan M, Turk Wensveen T, Polić B. The "Big Bang" in obese fat: Events initiating obesityinduced adipose tissue inflammation. Eur J Immunol. 2017; 45 (9): 2446-56.

[30] Belančić A, Kresović A, Rački V. Potential pathophysiological mechanisms leading to increased COVID-19 susceptibility and severity in obesity. Obes Med [Internet]. 2020; 19 (May): $100259 . \quad$ Available from: https://doi.org/10.1016/j.obmed.2020.100259

[31] Lee-Cervantes DE, Sánchez-Jiménez BA, Gutiérrez-Grobe Y, Yeverino-Suárez $\mathrm{P}$, Juárez-Hernández E, Chávez-Tapia NC. Clinical effect of obesity in the treatment of abdominal pain in the emergency department. Med Interna Mex. 2016; 30 (5): $546-53$.

[32] Ahn SY, Sohn SH, Lee SY, Park HL, Park YW, Kim H, et al. The effect of lipopolysaccharide-induced obesity and its chronic inflammation on influenza virus-related pathology. Environ Toxicol Pharmacol [Internet]. 2015; 40 (3): 924-30. Available from: http://dx.doi.org/10.1016/j.etap.2015.09.020

[33] Alves A, Quispe A, Ávila A, Valdivia A, Chino J, Vera O. Brief history and pathophysiology of COVID-19. Diagnostic Guide and COVID-19 Treatment in Ter Intensive Units for Boliv [Internet]. 2020; 61 (1): 77-86. Available from: http://www.scielo.org.bo/scielo.php?pid=S1652$67762020000100011 \&$ script $=$ sci_arttext

[34] Wouters OJ, Shadlen KC, Salcher-Konrad M, Pollard AJ, Larson HJ, Teerawattananon Y, et al. Challenges in ensuring global access to COVID-19 vaccines: production, affordability, allocation, and deployment. Lancet [Internet]. 2021; $6736 \quad$ (21): 1-12. Available from: http://dx.doi.org/10.1016/S0140-6736(21)00306-8 
[35] Kass DA, Duggal P, Cingolani O. Obesity could shift severe COVID-19 disease to younger ages. Lancet [Internet]. 2020; 395 (10236): 1544-5. Available from: http://dx.doi.org/10.1016/S0140-6736(20)31024-2

[36] Zhou F, Yu T, Du R, Fan G, Liu Y, Liu Z, et al. Clinical course and risk factors for mortality of adult inpatients with COVID19 in Wuhan, China: a retrospective cohort study. Lancet [Internet]. 2020; 395 (10229): 1054-62. Available from: http:///dx.doi.org/10.1016/S0140-6736 (20) 30566-3

[37] Mehanna O, Askary A El, Ali E, Esawy B El, Fathalla T, Gharib AF. Impact of obesity and its associated comorbid conditions on COVID-19 presentation. Diabetes, Metab Syndr Obes Targets Ther. 2021; 14: 409-15.

[38] Afolabi HA, Zakariya Z bin, Ahmed Shokri A Bin, Mohammad Hasim MN Bin, Vinayak R, Afolabi-Owolabi OT, et al. The relationship between obesity and other medical comorbidities. Obes Med [Internet]. 2020; 17 (November 2019): $100164 . \quad$ Available from: https://doi.org/10.1016/j.obmed.2019.100164

[39] Wang B, Li R, Lu Z, Huang Y. Does comorbidity increase the risk of patients with COVID-19. Aging (Albany NY). 2020; 12 (7): 6049-57.

[40] Goossens GH. The Metabolic Phenotype in Obesity: Fat Mass, Body Fat Distribution, and Adipose Tissue Function. Obes Facts. 2017; 10 (3): 207-15.

[41] Cândido FG, Valente FX, Grześkowiak ŁM, Moreira APB, Rocha DMUP, Alfenas R de CG. Impact of dietary fat on gut microbiota and low-grade systemic inflammation: mechanisms and clinical implications on obesity. Int $\mathrm{J}$ Food Sci Nutr [Internet]. 2018; 69 (2): 125-43. Available from: https://doi.org/10.1080/09637486.2017.1343286

[42] Al-Benna S. Association of high level gene expression of ACE2 in adipose tissue with mortality of COVID-19 infection in obese patients. Obes Med [Internet]. 2020; 19 (July): 100283. Available from: https://doi.org/10.1016/j.obmed.2020.100283

[43] Bourgonje AR, Abdulle AE, Timens W, Hillebrands JL, Navis GJ, Gordijn SJ, et al. Angiotensin-converting enzyme 2 (ACE2), SARS-CoV-2 and the pathophysiology of coronavirus disease 2019 (COVID-19). J Pathol. 2020; 251 (3): $228-48$.

[44] Bello-Chavolla OY, González-Díaz A, Antonio-Villa NE, Fermín-Martínez CA, Márquez-Salinas A, Vargas-Vázquez A, et al. Unequal Impact of Structural Health Determinants and Comorbidity on COVID-19 Severity and Lethality in Older Mexican Adults: Considerations Beyond Chronological Aging. Journals Gerontol Ser A. 2020; 76 (3): 52-9.

[45] Upadhyay J, Farr O, Perakakis N, Ghaly W, Mantzoros C. Obesity as a Disease. Med Clin North Am [Internet]. 2018; 102 (1): 13-33. Available from: https://doi.org/10.1016/j.mcna.2017.08.004

[46] Pranata R, Lim MA, Yonas E, Vania R, Lukito AA, Siswanto $\mathrm{BB}$, et al. Body mass index and outcome in patients with COVID-19: A dose - response meta-analysis. Diabetes Metab [Internet]. 2020; 1-9. Available from: https://doi.org/10.1016/j.diabet.2020.07.005

[47] Petrova D, Salamanca-Fernández E, Rodríguez Barranco M, Navarro Pérez P, Jiménez Moleón JJ, Sánchez MJ. Obesity as a risk factor in COVID-19: Possible mechanisms and implications. Aten Primaria [Internet]. 2020; 52 (7): 496-500. Available from: https://doi.org/10.1016/j.aprim.2020.05.003

[48] Velázquez LC. COVID-19: a challenge for global science. An Acad Ciencias Cuba. 2020; 10 (2): 763.

[49] Lázaro Díaz-Rodríguez Y, Amado Quintana-López L. "COVID19. From pathogenesis to high mortality in the elderly and with comorbidities. "Rev Habanera Medical Sciences [Internet]. 2020 [cited 2021 Mar 26]; 19. Available from: http://www.revhabanera.sld.cu/index.php/rhab/article/view/3531

[50] Rico J, Daza R, Galvis N, Martínez V, Franco E, López J, et al. Obesity and Covid-19. Arch Medi. 2020; 16 (4): 1-5.

[51] Salinas-Aguirre JE, Sánchez-García C, Rodríguez-Sanchez R, Rodríguez-Muñoz L, Díaz-Castaño A, Bernal-Gómez R. Clinical characteristics and comorbidities associated with mortality in patients with COVID-19 in Coahuila (Mexico). Rev Clínica Española. 2021; (1): 6-10. 